УДК 336.232.3

Ватаманюк-Зелінська У.З., д.е.н., професор Професор кафедри фінансового менеджменту

Беднарчук В.В. бакалавр Млінцова А.О. бакалавр Vatamanyuk-Zelinska U. Z., Doctor of Science (Economics), professor Professor of the Department of Financial Management https://orcid.org/0000-0003-4971-5763 Bednarchuk V.V.

Bachelor

https://orcid.org/0000-0002-7666-5477 Mlintsova A.O.

Bachelor

https://orcid.org/0000-0002-7953-0703

\title{
ФІСКАЛЬНЕ ЗНАЧЕННЯ ЗБОРУ ЗА МІСЦЯ ДЛЯ ПАРКУВАННЯ ТРАНСПОРТНИХ ЗАСОБІВ ДЛЯ ЕКОНОМІКИ МІСТА ЛЬВОВА
}

\author{
Львівський начіональний університет ім. Івана Франка
}

\begin{abstract}
В статті визначено фіскальне значення збору за місця паркування транспортних засобів для економіки міста Львова. Розглянуто нормативно-правову базу, яка регулює функціонування збору за місця для паркування транспортних. Наведено характеристику обов'язкових елементів збору за місця для паркування транспортних засобів, а саме платників податку, об'єкт оподаткування, базу оподаткування та ставку збору. Відзначено, що суму збору за паркування транспортних засобів визначають за 1 кв. метр площі земельної ділянки, відведеної для паркування, у розмірі до 0,075 \% мінімальної заробітної плати. Здійснено аналіз показників збору за місця для паркування в доходах бюджетів міст обласного значення у 2020 році. За результатами аналізу встановлено, що бюджет міста Львова в шестеро менший за столичний, а кількість населення нашого міста $є$ меншою в чотири рази, проте частка зборів за паркування в бюджеті міста Львова становить 0,1710\%, а в Києві лише 0,0038\%, що свідчить про провадження ефективної політики щодо організації, функціонування, ціноутворення, координації і контролю в галузі паркування транспортних засобів. Охарактеризовано фіскальну функцію збору за місця для паркування транспортних засобів на базі динаміки його надходжень до бюджету міста Львова. Розглянуто питому вагу цього збору у структурі місцевих податків бюджету міста Львова та в ході аналізу виявлено, що за аналізований період цей показник знаходиться у межах від 0,45\% у 2016 році до $0,75 \%$ у 2020 році, що вказує на зростання кількості транспортних засобів мешканців та гостей міста. Наведено плату за паркування одного транспортного засобу за годину у розрізі зон паркування міста Львова. Визначено, що передбачено п’ять зон паркування на території міста Львова. Також слід відзначити, що організація майданчиків для паркування на території міста Львова здійснюється за ініціативою органів державної влади та місцевого самоврядування чи за поданням суб'єктів підприємницької діяльності. Доведено, що збір за місця для паркування транспортних засобів є доволі перспективним джерелом поповнення місцевих бюджетів. Визначено характерні проблеми паркування та справляння збору за місця для паркування транспортних засобів. На основі здійсненого дослідження уточнено тенденції та визначено напрями органів місцевого самоврядування для вирішення проблем цієї сфери.
\end{abstract}

Ключові слова: місцевий бюджет, збір за місця паркування транспортних засобів, принцип фіскальної достатності, місцеві податки, Україна.

\section{FISCAL SIGNIFICANCE OF TAXES FOR PARKS OF VEHICLES FOR ECONOMY OF THE CITY OF LVIV}

\author{
Ivan Franko Lviv National University
}

Lviv.

The article defines the fiscal significance of the fee for parking vehicles for the economy of the city of 
The normative-legal base, which regulates the functioning of the fee for parking places for vehicles, is considered. The characteristics of the obligatory elements of the fee for parking spaces for vehicles, namely the taxpayers, the object of taxation, the tax base and the fee rate are given. It is noted that the amount of the fee for parking vehicles is determined per 1 square meter of land allocated for parking, up to $0.075 \%$ of the minimum wage. An analysis of the indicators of the fee for parking spaces in the revenues of budgets of cities of regional importance in 2020 . According to the analysis, the budget of the city of Lviv is six times smaller than the capital, and the population of our city is four times smaller, but the share of parking fees in the budget of the city of Lviv is $0.1710 \%$, and in Kiev only $0.0038 \%$, indicating the implementation of an effective policy on the organization, operation, pricing, coordination and control in the field of vehicle parking. The fiscal function of collecting for parking places of vehicles on the basis of dynamics of its receipts to the budget of the city of Lviv is characterized. The share of this fee in the structure of local taxes of the budget of the city of Lviv is considered and during the analysis it is revealed that for the analyzed period this indicator is in the range from $0.45 \%$ in 2016 to $0.75 \%$ in 2020 , which indicates an increase in vehicles of residents and guests of the city. There is a fee for parking one vehicle per hour in terms of parking zones of the city of Lviv. It has been determined that there are five parking zones in the city of Lviv. It should also be noted that the organization of parking lots in the city of Lviv is carried out on the initiative of public authorities and local governments or at the request of business entities. It is proved that the fee for parking spaces for vehicles is a very promising source of replenishment of local budgets. Typical problems of parking and collection of parking fees for vehicles have been identified. On the basis of the conducted research the tendencies are specified and the directions of local governments for the decision of problems of this sphere are defined.

Key words: local budget, vehicle parking fee, the principle of fiscal sufficiency, local taxes, Ukraine.

Постановка проблеми у загальному вигляді i iï зв'язок 3 важливими науковими та практичними завданнями. Сьогодення в українській державі характеризується завершенням процесу децентралізації, коронакризою та важкою ситуацією на сході країни. У зв'язку із цим, важливого значення набувають питання наповнення місцевих бюджетів додатковими фінансовими ресурсами. В сучасних умовах місцеві податки і збори стають важливими джерелами формування дохідної частини бюджетів місцевого самоврядування, сприяючи соціально-економічному розвитку територій та місцевої інфраструктури.

Ключовими принципами організації податкової системи є принцип фіскальної достатності та принцип соціальної справедливості, які тісно взаємопов'язані. Тому що встановлення податків та зборів повинно здійснюватись 3 урахуванням платоспроможності платників податку та 3 урахуванням необхідності досягнення збалансованості витрат бюджету з його надходженнями. Збір за місця для паркування транспортних засобів грунтується на даних принципах, оскільки стягується 3 метою наповнення бюджету для здійснення необхідних витрат та встановлюється відповідно до фінансових можливостей населення окремих регіонів.

Аналіз останніх досліджень, у яких започатковано вирішення проблеми. Інституту місцевого оподаткування приділено багато уваги 3 боку вітчизняних та закордонних науковців, зокрема Сидор І.П. та Карпишин Н.I. вивчали значення місцевого оподаткування в Україні в контексті фінансового забезпечення суспільних послуг [1]. Бак Н.А. аналізувала стан місцевого оподаткування, розглядаючи перспективи посилення його дієвості [2]. Проць Н.В. визначила фіскальну роль місцевих податків та зборів в умовах реформування бюджетного та податкового законодавства [3]. Ніколаєва О.М. та Маглаперідзе А.С. розглядали методи посилення дохідної бази місцевих бюджетів, вивчаючи правові аспекти справляння збору за місця паркування транспортних засобів та проблематику його застосування органами місцевої влади [4]. Відомі дослідження О.В. Костяна та В.В. Ясько щодо практики наповненості місцевих бюджетів шляхом встановлення (відміни) цього збору, - вони визначали та характеризували особливості справляння збору за місця для паркування транспортних засобів на прикладі міста Чугуєва [5].

Мета статті. Комплексне дослідження особливостей справляння збору за місця для паркування транспортних засобів та встановлення його фіскального значення для економіки міста Львова. 
Виклад основного матеріалу дослідження 3 повним обгрунтуванням отриманих наукових результатів. В Україні до кінця 2014 року розвиток та організація процесів формування доходів місцевих бюджетів характеризувалися високим рівнем залежності від державної фінансової допомоги. Встановлення вимог щодо справляння місцевих податків та зборів і пільг щодо них є децентралізованим так як відбувається на основі рішення відповідних місцевих рад. Ефективний розвиток міст, потребує належного фінансового забезпечення і залежить від джерел доходів їх місцевих бюджетів. Запровадження збору за паркування транспортних засобів у містах 3 інтенсивним режимом руху транспортних потоків сприятиме фінансуванню видатків на покращення місцевої інфраструктури. Адже його встановлення забезпечує таку можливість.

Зазначимо, що під час прийняття рішення про встановлення місцевого збору обов'язково визначаються усі його обов'язкові елементи (рис. 1) [6].

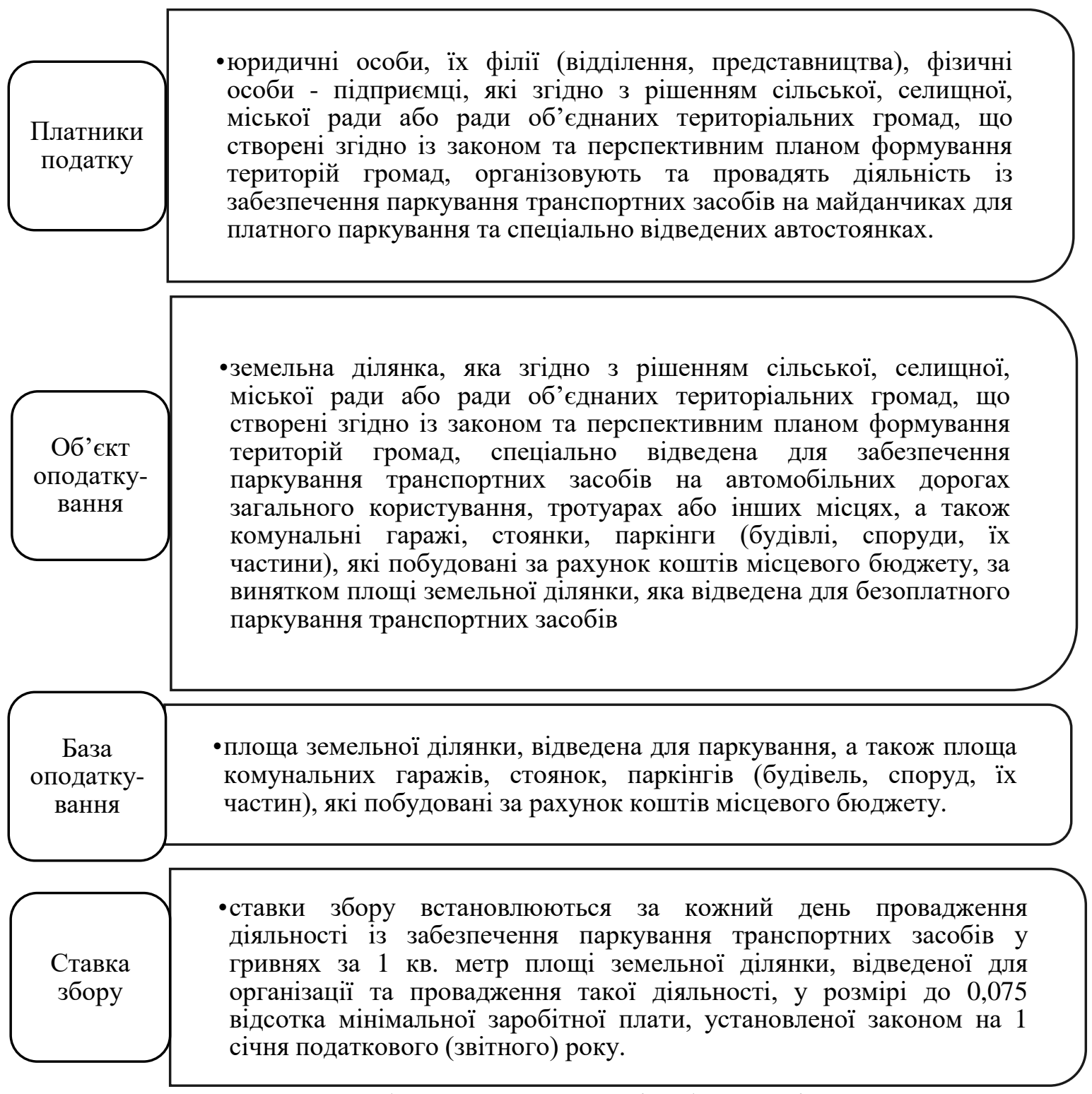

Рис. 1. Характеристика обов'язкових елементів збору за місця для паркування транспортних засобів [7]

У вітчизняному податковому законодавстві зазначається, що збір за місця для паркування транспортних засобів $є$ місцевим збором. Згідно 3 статтею 10.3 
Податкового кодексу України [6], місцеві ради в межах своїх повноважень, вирішують питання щодо його встановлення. А нормативно-правова база, яка регулює функціонування збору за місця для паркування транспортних включає: Податковий кодекс України [6]; наказ Міністерства фінансів України «Про затвердження форм податкових декларацій збору за місця для паркування транспортних засобів та туристичного збору» [7]; правила паркування транспортних засобів, затверджені Постановою Кабінету Міністрів України від 03.12.2009 [8]; порядок формування тарифів на послуги з утримання майданчиків для платного паркування транспортних засобів, затверджений Постановою Кабінету Міністрів України від 02.03.2010 [9]; рішення міських, селищних та сільських рад щодо встановлення на відповідній територій місцевих податків і зборів; Закон України Про Державний бюджет України на відповідний рік.

Із метою підвищення фіскальної ролі збору за місця для паркування транспортних засобів у доходах місцевих бюджетів, органи місцевого самоврядування мають встановлювати доцільні i обгрунтовані їх розміри. Для цього необхідно враховувати рівень платоспроможності громадян та суб'єктів господарювання i, відповідно, потреби наповнення міського бюджету.

Відповідно до Податкового кодексу України [7], державою встановлюються граничні розміри місцевих податків та зборів, проте органи місцевого самоврядування, в силу своїх повноважень, можуть визначати їх конкретні величини. Розмір більшості місцевих податків і зборів залежить від величини мінімальної зарплати, який також встановлюється законодавчо. Суму збору за паркування транспортних засобів визначають за 1 кв. метр площі земельної ділянки, відведеної для паркування, у розмірі до $0,075 \%$ мінімальної зарплати, тобто зараз це 4,5 грн., оскільки місячний розмір мінімальної заробітної плати з 1 січня 2021 року становить 6000 гривень [10].

За допомогою цього збору відбувається забезпечення фіскальної достатності місцевих бюджетів. Проте, збір за паркування транспортних засобів встановлений тільки в 12 обласних центрах України (таблиця 1).

Таблиця 1

Аналіз показників збору за місця для паркування в доходах бюджетів міст обласного значення, 2020 р. [11]

Обласний центр

Київ
Одеса
Львів
Дніпро
Харків
Тернопіль
Івано-Франківськ
Чернівці
Чернігів
Херсон
Луцьк
Хмельницький
Вінниця, Житомир, Ужгород,
Запоріжжя, Кропивницький,
Миколаїв, Полтава, Рівне,
Суми, Черкаси
Донецьк, Луганськ

\section{Київ}

Львів

Дніпро

Івано-Франківськ

Чернівці

Чернігів

Херсон

Вінниця, Житомир, Ужгород, Запоріжжя, Кропивницький, Суми, Черкаси

Донецьк, Луганськ
Дохід від паркінгів на душу населення обласного центру, грн. 0,755 32,15

21,41

18,48

8,13

7,95

7,11

3,67

2,82

0,97

0,29

0,07

збір відсутній

інформація відсутня

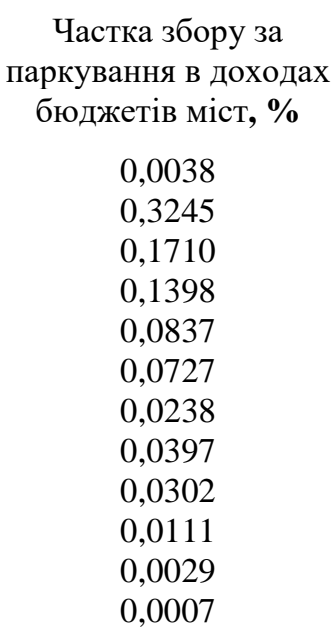

збір відсутній 
Як бачимо, в умовному рейтингу результативності експлуатації міських паркінгів перше місце посідає м. Одеса (див. табл. 1). Обсяг надходжень збору за місця для паркування в цьому місті у 2020 році становив 32725,01 тис. грн., випереджаючи по обсягах аналогічних надходжень м. Львів на 17214,5 тис. грн. Натомість позиція м. Львова у рейтингу є вищою порівняно із столицею, адже за обсягами надходжень збору наше місто випереджає м. Київ 3 різницею у розмірі 13271,03 тис. грн.). Рекордний для України показник величини частки збору за паркування в доходах бюджетів міст також належить м. Одесі - 0,3245\%. Це місто очолює й рейтинг доходів від паркінгів на душу населення (32,15 грн. на одну людину).

Бюджет м. Львова в шестеро менший за столичний, а кількість населення нашого міста є меншою в чотири рази, проте частка зборів за паркування в бюджеті м. Львова становить $0,1710 \%$, а в Києві лише 0,0038\%. Це свідчить про провадження ефективної політики щодо організації, функціонування, ціноутворення, координації i контролю в галузі паркування транспортних засобів, яка, тим не менше, має постійно удосконалюватись. Своєю чергою, такий досвід стане корисним для інших міст та дасть змогу забезпечити належний благоустрій вуличнодорожньої мережі, збільшення пропускної спроможності проїзних частин вулиць, підвищення безпеки дорожнього руху, дисципліни водіїв, впровадження культури паркування. Таким чином, впровадження збору за місця для паркування сприяє досягненню фіскальної достатності місцевих бюджетів.

Принцип фіскальної достатності має певне кордонне значення на межі бюджетного та податкового регулювання. 3 одного боку, справляння податків не $є$ самоціллю, вони справляються не просто для формування дохідних частин бюджетів, а 3 метою такого їх формування, яке б забезпечило виконання усіх завдань і функцій держави та територіальних громад. 3 іншого боку, цим принципом пропонується i певне обмеження свавілля під час встановлення податків та зборів. Їх розмір та види не можуть бути нескінченними, а лише забезпечувати необхідні надходження до бюджетів [12].

Доцільним буде охарактеризувати фіскальну функцію збору за місця для паркування транспортних засобів на базі динаміки його надходжень до бюджету м. Львова (рис.2).

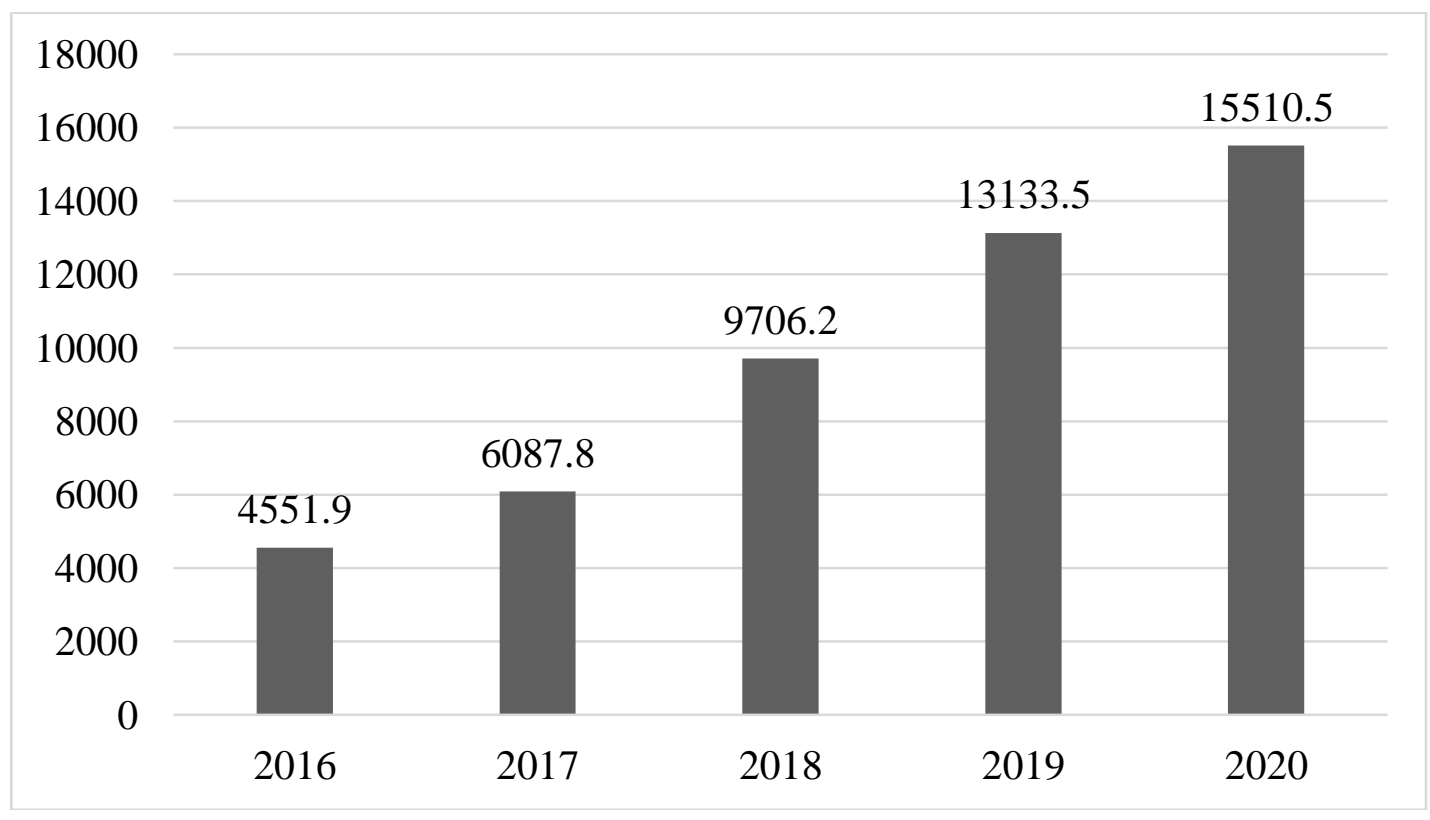


Рис. 2. Динаміка надходжень збору за місця для паркування транспортних засобів до бюджету міста Львова за період 2016-2020 pр., тис. грн. [13]

Зауважимо, що протягом останніх років у бюджеті міста Львова відбувається постійне та стрімке збільшення обсягів надходжень збору за місця для паркування транспортних засобів. Так, станом на 31.12.2016 року обсяг збору становив 4511,9 тис. грн., а вже станом на 31.12.2020 року він зріс на 10998,6 тис. грн., або на 70,9\% до 15510,5 тис. грн., що є цілком прийнятним показником для міста обласного значення. Відмітимо також, що щорічні темпи приросту даного збору за період 2016-2020 pp. становлять, відповідно, 9, 26, 37, 35, 18\%, що пов'язано з посиленням контролю за сплатою даного збору.

Для більш поглибленого аналізу збору за місця для паркування транспортних засобів розглянуто питому вагу цього збору у структурі місцевих податків бюджету міста Львова (рис. 3).

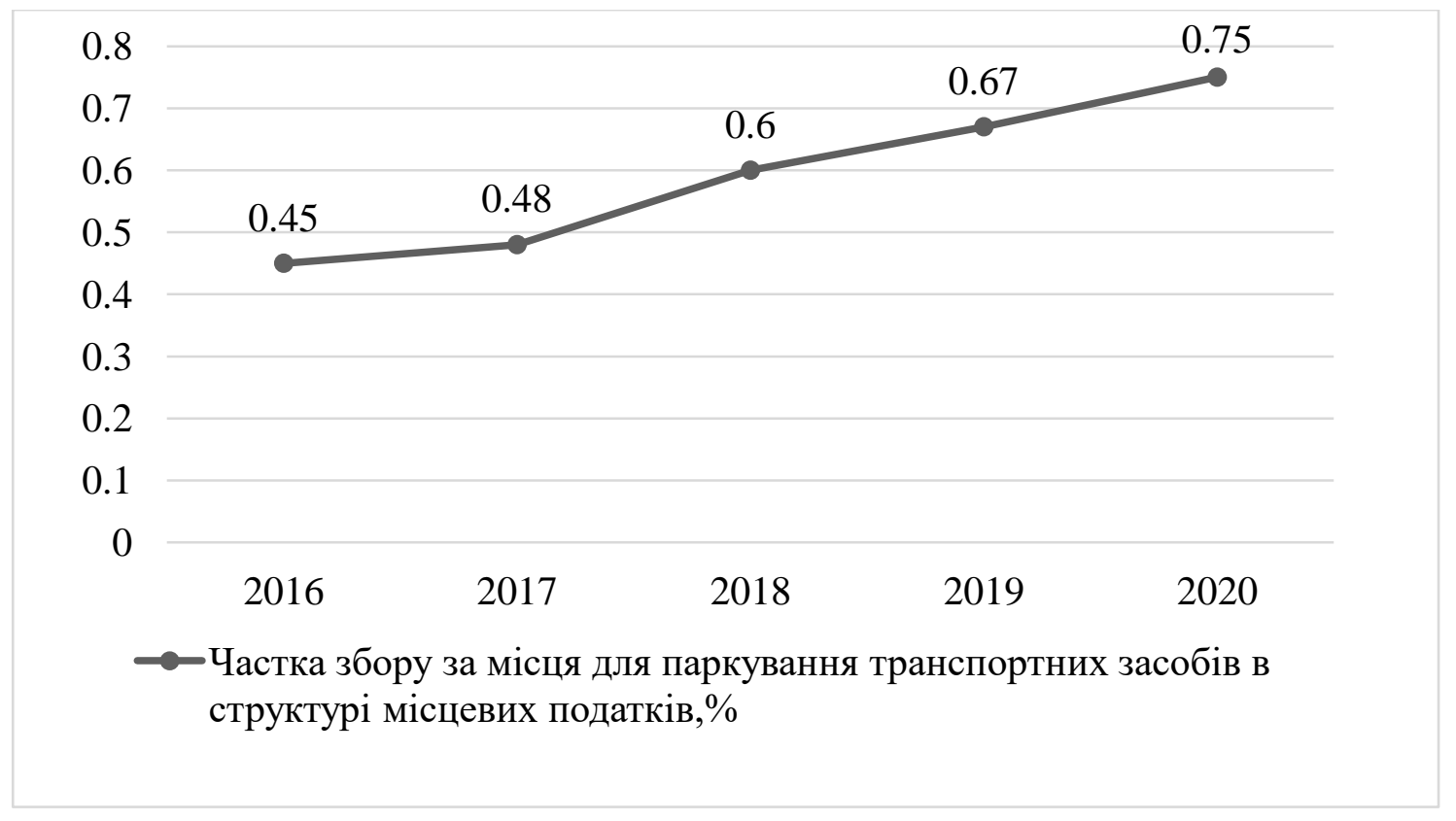

Рис. 3. Динаміка частки збору за місця для паркування транспортних засобів в структурі місцевих податків бюджету міста Львова,\% [13]

Оскільки надходження до бюджету м. Львова від збору за місця для паркування транспортних засобів зростають високими темпами то, аналогічно, збільшується його питома вага у структурі місцевих податків і зборів. Так, за аналізований період цей показник знаходиться у межах від $0,45 \%$ у 2016 році - до $0,75 \%$ у 2020 році, що вказує на зростання кількості транспортних засобів мешканців та гостей міста.

Організація майданчиків для паркування на території міста Львова здійснюється за ініціативою органів державної влади та місцевого самоврядування чи за поданням суб'єктів підприємницької діяльності за попереднім погодженням 3 уповноваженим органом ГУ Національної поліції України у Львівській області та адміністрації відповідного району міста. Сьогодні передбачено п'ять зон паркування на території м. Львова. Для прикладу, до першої зони, де вартість паркування найдорожча - не більше 30,00 грн. за годину, включаються центральна частина міста, яка обмежена вулицями: просп. Свободи, пл. Князя Ярослава Осмомисла, вул. С. Гавришкевича, вул. Підвальною, вул. Валовою, пл. А. Міцкевича [14]. 
Плата за паркування одного транспортного засобу за годину у розрізі зон паркування подана у таблиці 2.

Таблиця 2

Плата за паркування одного транспортного засобу за годину у розрізі зон паркування

\section{[14]}

№ Зони

Плата за паркування одного транспортного засобу за годину На спеціально обладнаних майданчиках для платного паркування у 1-й зоні паркування - не більше 30,00 грн.

Зона I більше 20,00 грн.

Зона II

На відведених майданчиках для платного паркування у 1-й зоні паркування - не

Зона III

На майданчиках для платного паркування у 2-й зоні паркування - не більше 15,00 грн

На майданчиках для платного паркування у 3-й зоні паркування - не більше 10,00 грн.

Зона IV

Зона V

(функціональна) грн.

На майданчиках для платного паркування у 4-й зоні паркування - не більше 5,00

На майданчиках для платного паркування туристичного транспорту (незалежно від місця розташування) - не більше 80,00 грн

В умовах розвитку сучасної інфраструктури м. Львова, який пов'язаний із прагненням до підвищення життєвих стандартів, розвиванням провідних галузей промисловості, «розквітом» сфери будівництва та збільшенням кількості населення, важливо приділити увагу проблемам паркування та справляння збору за місця для паркування транспортних засобів. Зокрема, необхідні заходи регуляторного впливу 3 боку місцевої влади, які запобігають:

- паркуванню в заборонених місцях, на тротуарах, адже - це результат недостатнього контролю за виконанням правил дорожнього руху, внаслідок чого утворюються аварійні ситуацій на дорозі;

- перевантаженню міста транспортними засобами;

- нераціональному та неефективному збору плати за паркування, яке пов'язане iз тим, що не всі учасники дорожнього руху ознайомленні з Правилами паркування транспортних засобів [8];

- непрозорій діяльності у сфері паркінгу.

Висновки. В сучасних умовах, дослідження фіскальної функції та особливостей збору за місця для паркування транспортних засобів на прикладі міста Львова, дає змогу зрозуміти важливість цього джерела надходжень під час прогнозування дохідної частини бюджету. Проте в Україні майже половина обласних центрів не заробляє на паркінгах. Деякі міські ради не включають даного збору у податкові надходження, а деякі неефективно провадять політику у сфері організації, функціонування, ціноутворення, координації і контролю в галузі паркування транспортних засобів. Проте, результати досліджень свідчать, що збір за місця для паркування транспортних засобів $є$ доволі перспективним джерелом поповнення місцевих бюджетів. Важливими кроками ОМС для вирішення проблем цієї сфери стануть:

- підвищення ефективності контролю за паркуванням в заборонених місцях та процедурою обчислення збору за місця для паркування транспортних засобів;

- покращення обізнаності населення щодо Правил паркування транспортних засобів із метою ознайомлення потенційних платників збору з рішеннями місцевих органів самоврядування; 
- зміни системи місцевого оподаткування та розширення законодавчої бази щодо визначення аспектів регулювання даного збору;

- підвищення рівня прозорості справляння даного податку і уникнення тіньової економіки у цій сфері;

- збільшення рівня зацікавленості влади на місцевому рівні в збільшені дохідної частини місцевих бюджетів;

- вивчення світового досвіду здійснення оподаткування у цій сфері, а також забезпечення впровадження процедур, принципів і стандартів паркування, шляхом удосконалення чинної нормативно-правової бази для покращення благоустрою населених пунктів.

\section{Список бібліографічного опису}

1. Сидор І. П., Карпишин Н. І. Місцеве оподаткування в Україні в контексті фінансового забезпечення суспільних послуг. Ефективна економіка. 2020. № 9. Режим доступу: http://www.economy.nayka.com.ua/pdf/9_2020/58.pdf (дата звернення: 08.04.2021).

2. Бак Н. А. Місцеве оподаткування в України: стан і перспективи посилення дієвості. Економіка: реалії часу. 2017. №1 (29). Режим доступу: https://economics.opu.ua/files/archive/2017/No1/12.pdf (дата звернення: 08.04.2021).

3. Проць Н. В. Сутність та фіскальна роль місцевих податків та зборів в умовах реформування бюджетного та податкового законодавства. Гроші, фінанси і кредит. Випуск 13. 2016. С. 536-541. Режим доступу: http://globalnational.in.ua/issue-13-2016/21-vipusk-13-zhovten-2016-r/2473-prots-n-v-sutnist-ta-fiskalna-rol-mistsevikh-podatkiv-tazboriv-v-umovakh-reformuvannya-byudzhetnogo-ta-podatkovogo-zakonodavstva (дата звернення: 08.04.2021).

4. Ніколаєва О.М., Маглаперідзе А. С. Місцеві фінанси: навч. посібник. Київ: «Центр учбової літератури», 2013. $354 \mathrm{c}$.

5. Костяна О. В., Ясько В. В. Особливості справляння збору за місця паркування транспортних засобів на прикладі міста Чугуєва. Гроші, фінанси i кредит. Випуск 16. 2017. С. 710-714. Режим доступу: file:///F:/\%D1\%81\%D1\%82\%D0\%B0\%D1\%82\%D1\%82\%D1\%8F\%202021\%20\%D0\%B2-\%D0\%B7/139.pdf (дата звернення: 08.04.2021).

6. Податковий кодекс України: Закон України від 02.12.2010 p. № 2755-VI. Відомості Верховної Ради України. 2011. Режим доступу: https://zakon.rada.gov.ua/laws/show/2755-17\#Text (дата звернення: 09.04.2021).

7. Про затвердження форм податкових декларацій збору за місця для паркування транспортних засобів та туристичного збору: Наказ Міністерства фінансів України від 09.07.2015 р. №z0912-15. Дата оновлення: 13.03.2020. Режим доступу: https://zakon.rada.gov.ua/laws/show/z0912-15\#Text (дата звернення: 09.04.2021).

8. Правила паркування транспортних засобів, затверджені Постановою Кабінету Міністрів України від 03.12.2009 №1342. Дата оновлення: 06.04.2021. Режим доступу: https://zakon.rada.gov.ua/laws/show/1342-2009-\%D0\%BF\#Text (дата звернення: 09.04.2021).

9. Порядок формування тарифів на послуги з утримання майданчиків для платного паркування транспортних засобів, затверджений Постановою Кабінету Міністрів України від 02.03.2010. №258-2010-п. Дата оновлення: 03.11.2020. Режим доступу: https://zakon.rada.gov.ua/laws/show/258-2010-\%D0\%BF\#Tеxt (дата звернення: 09.04.2021). 10. Про Державний бюджет України на 2021 рік: Закон України від 15.12.2020. №1082-IX. Дата оновлення: 31.01.2021. Режим доступу: https://zakon.rada.gov.ua/laws/show/1082-20\#Tеxt (дата звернення: 11.04.2021).

11. Державний веб-портал бюджету для громадян (за даними Міністерства фінансів України). Режим доступу: https://openbudget.gov.ua/ (дата звернення: 11.04.2021).

12. Барабаш О. О. Принцип фіскальної достатності у податковому законодавстві України. Національний університет «Львівська політехніка». 2014. С.46-50. Режим доступу: http://ena.lp.edu.ua:8080/bitstream/ntb/26483/1/10-46-50.pdf (дата звернення: 11.04.2021).

13. Офіційний сайт Львівської міської ради. Режим доступу: https://city-adm.lviv.ua/publicinformation/budget/lviv/biudzhet-lvova-na-2020-rik (дата звернення: 13.04.2021).

14. Про внесення змін до ухвал міської ради від 27.01.2011 № 120 та від 29.12.2011 № 1072: Ухвала Львівської

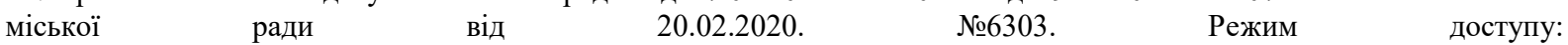
https://www8.cityadm.lviv.ua/inteam/uhvaly.nsf/(SearchForWeb)/E348855D179F4F11C225851B00530F5D?OpenDocumen t (дата звернення: 13.04.2021).

\section{References}

1. Sydor I. P. and Karpyshyn N. I. (2020), "The place of taxation in Ukraine in the context of financial provision of public services", Efektyvna ekonomika, [Online], vol. 16, available at: http://www.economy.nayka.com.ua/pdf/9_2020/58.pdf (Accessed 8 April 2021).

2. Bak N. A. (2017), "The place of taxation in Ukraine: the state and prospects of strengthening legal capacity”, Ekonomika: realii chasu, [Online], vol. 1 (29), available at: https://economics.opu.ua/files/archive/2017/No1/12.pdf (Accessed 8 April 2021).

3. Prots N. V. (2016), “ The essence and fiscal role of local taxes and fees in terms of reforming budget and tax legislation ", Hroshi, finansy i kredyt, [Online], vol. 13, available at: http://global-national.in.ua/issue-13-2016/21-vipusk-13-zhovten2016-r/2473-prots-n-v-sutnist-ta-fiskalna-rol-mistsevikh-podatkiv-ta-zboriv-v-umovakh-reformuvannya-byudzhetnogo-tapodatkovogo-zakonodavstva (Accessed 8 April 2021). 
4. Nikolaieva O.M. and Mahlaperidze A. S. (2013), Mistsevi finansy [Local finances], Tsentr uchbovoi literatury, Kyiv, Ukraine. [in Ukrainian].

5. Kostiana O. V. And Yasko V. V. (2017), "Peculiarities of collecting vehicle parking fees on the example of the city of Chuguev", Hroshi, finansy $i$ kredyt, [Online], vol. 16, available at: file:///F:/\%D1\%81\%D1\%82\%D0\%B0\%D1\%82\%D1\%82\%D1\%8F\%202021\%20\%D0\%B2-\%D0\%B7/139.pdf (Accessed 8 April 2021).

6. The Verkhovna Rada of Ukraine (2011), The Law of Ukraine "Tax Code of Ukraine", available at: https://zakon.rada.gov.ua/laws/show/2755-17\#Text (Accessed 9 April 2021).

7. Order of the Ministry of Finance of Ukraine (2015), "About the statement of forms of the tax declarations of a charge for places for parking of vehicles and a tourist tax", available at: https://zakon.rada.gov.ua/laws/show/z0912-15\#Text (Accessed 9 April 2021).

8. Cabinet of Ministers of Ukraine (2009), "Vehicle parking rules", available at: https://zakon.rada.gov.ua/laws/show/13422009-\%D0\%BF\#Text (Accessed 9 April 2021).

9. Cabinet of Ministers of Ukraine (2010), "The order of formation of tariffs for services on the maintenance of platforms for paid parking of vehicles", available at: https://zakon.rada.gov.ua/laws/show/258-2010-\%D0\%BF\#Text (Accessed 9 April 2021).

10. The Verkhovna Rada of Ukraine (2020), The Law of Ukraine “About the State Budget of Ukraine for 2021", available at: https://zakon.rada.gov.ua/laws/show/1082-20\#Text (Accessed 11 April 2021).

11. State web portal of the budget for citizens (according to the Ministry of Finance of Ukraine), available at: https://openbudget.gov.ua/ (Accessed 11 April 2021).

12. Barabash O. O. (2014), "The principle of fiscal sufficiency in the tax legislation of Ukraine". Natsionalnyi universytet «Lvivska politekhnika», [Online], available at: http://ena.lp.edu.ua:8080/bitstream/ntb/26483/1/10-46-50.pdf (Accessed 11 April 2021).

13. Official site of Lviv City Council, available at: https://city-adm.lviv.ua/public-information/budget/lviv/biudzhet-lvova-na2020-rik (Accessed 13 April 2021).

14. Lviv City Council (2011), "About modification of decisions of city council from 27.01.2011 № 120 and from 29.12 .2011 № 1072”, available at: https://www8.cityadm.lviv.ua/inteam/uhvaly.nsf/(SearchForWeb)/E348855D179F4F11C225851B00530F5D?OpenDocumen t (Accessed 13 April 2021).

Дата подання публікації 05.05.2021 р.

УДК 336.14

Кузьмак О.М., д.е.н., професор

Kuzmak O. Doctor of Economic Sciences, Professor https://orcid.org/0000-0003-0394-0981

\title{
СВІТОВИЙ ДОСВІД ФОРМУВАННЯ БЮДЖЕТНОГО ПОТЕНЦІАЛУ МІСЦЕВИХ ФІНАНСІВ В УМОВАХ ДЕЦЕНТРАЛІЗАЦІЇ
}

\author{
Луцький національний технічний університет
}

У статті визначено, що відповідно до реформи децентралізації, актуальним на сьогодні аспектом $є$ дослідження світового досвіду формування та витрачання місцевих бюджетів. Досліджено бюджетний устрій країн Європи. Економічна та фінансова децентралізація привела до формування міжурядових фінансових відносин, що поєднують у собі принципи як бюджетного унітаризму, так і бюджетного федералізму. Досліджено трактування поняття бюджетного унітаризму та федералізму. Проаналізовано частки доходів місцевих бюджетів у ВВП в країнах Європи. Досліджено, що В СС дев'ять країн використовують лише один рівень піддержавних органів влади (самоврядування); інші дванадцять країн мають два регіональні рівні (муніципалітети та регіони); тоді як решта сім мають три рівні нижче загальнодержавного (муніципалітети, регіони та суб'єкти посередницької діяльності). Визначено, що конституції деяких країн іноді взагалі не регулюють організацію місцевого самоврядування (наприклад, у США).

Оцінено досвід європейських країн щодо обсягу надходжень до бюджету від місцевих податків. Здійснено аналіз динаміки бюджетного потенціалу місцевих фінансів Рівненської області. Визначено, що найважливішим економічним інструментом $\epsilon$ бюджет, тоді як управління місцевими органами самоврядування відповідно до встановленого бюджету є обов'язковим за законом у кожній країні. Запропоновано шляхи збільшення податкової складової бюджетного потенціалу місцевих фінансів. 
Окреслено шляхи пошуку альтернативних джерел наповнення місцевих бюджетів через впровадження неподаткових зборів.

Ключові слова: децентралізація, місиеве самоврядування, місиеві бюджети, бюджетний унітаризм, бюджетний федералізм, бюджетний потенціал, доходи та видатки місцевих бюджетів. 